\title{
Estudo comparativo entre metodologias de triagem para detecção de hemoglobina $S$ em bancos de sangue
}

Primeira submissão em 09/07/10 Última submissão em 03/12/10 Aceito para publicação em 10/01/11 Publicado em 20/04/11

\section{Comparative study between methods of screening for detection of hemoglobin $S$ in the blood banks}

Letícia Loi Giovelli'; Karina Danielii; Adriana Najai Bortolotto ${ }^{3}$; Aline Klein Mastella4; Márcia Pinarello Prior ${ }^{5}$; Simone Martins Castro ${ }^{6}$; Carmen Julieta Arrua ${ }^{7}$; José Edson Paz da Silva ${ }^{8}$

\begin{tabular}{|c|c|}
\hline & \\
\hline $\begin{array}{l}\text { Hemoglobina S } \\
\text { Traço falciforme } \\
\text { Teste de solubilidade } \\
\text { Teste de gel-centrifugação } \\
\text { Eletroforese de } \\
\text { hemoglobina }\end{array}$ & $\begin{array}{l}\text { Introdução: O traço falciforme é a presença em heterozigose da hemoglobina } \mathrm{S} \text { (HbS). A partir de junho } \\
\text { de } 2004 \text {, por meio da RDC } 153 / 04 \text {, tornou-se obrigatória a triagem de hemoglobinas anormais em } \\
\text { doadores de sangue. Objetivo: O objetivo deste estudo foi a comparação de diferentes metodologias de } \\
\text { triagem utilizadas nos bancos de sangue para a detecção da HbS. Material e método: No período de } \\
\text { abril de } 2007 \text { a abril de } 2008 \text {, foram realizados três métodos de detecção de } \mathrm{HbS} \text { em } 4.108 \text { doadores de } \\
\text { sangue aptos que se apresentaram ao banco de sangue do Hospital Universitário de Santa Maria (HUSM). } \\
\text { O estudo comparativo entre as metodologias incluiu os testes de solubilidade e de gel-centrifugação, } \\
\text { tendo como referência de positividade a presença de } \mathrm{HbS} \text { na eletroforese de hemoglobina. Resultados: } \\
\text { Dos } 4.108 \text { doadores estudados, } 23(0,56 \%) \text { apresentaram resultado positivo para } \mathrm{HbS} \text { e dois (0,05\%) } \\
\text { para HbC. Das amostras positivas para } \mathrm{HbS} \text { detectadas por eletroforese qualitativa, } 22 \text { (95,6\%) foram } \\
\text { detectadas pelo teste de solubilidade e } 20 \text { ( } 86,9 \%) \text { pelo de gel-centrifugação. Conclusão: A eletroforese } \\
\text { de hemoglobinas representou a melhor metodologia na identificação de hemoglobinas variantes e, } \\
\text { portanto, deve ser valorizada quando se trata de diagnóstico para triagens em bancos de sangue pelo seu } \\
\text { grau de sensibilidade, minimizando ao máximo os resultados falsos negativos e garantindo a qualidade } \\
\text { do sanque que estará sendo utilizado. }\end{array}$ \\
\hline
\end{tabular}

abstract

Introduction: The sickle cell trait is the presence of hemoglobin $\mathrm{S}(\mathrm{HbS})$ in heterozygosity. According to RDC regulation 153/04, abnormal hemoglobin screening has become mandatory in blood donation samples since June 2004. Objective: The aim of this study was to compare different screening methods used in blood banks for HbS detection. Material and method: From April 2007 to April 2008, three HbS detection methods were applied in 4,108 suitable blood samples from the blood bank of the University Hospital of Santa Maria (HUSM). The comparative study among the methods comprised solubility tests and gel-centrifuge (ID-HbS). Furthermore, the positivity reference was the presence of $\mathrm{HbS}$ on hemoglobin electrophoresis. Results: Twentythree $(0.56 \%)$ out of 4,108 samples showed positivity for $\mathrm{HbS}$ and two $(0.05 \%)$ showed positivity for $\mathrm{HbC}$. Twenty-two (95.6\%) out of $23 \mathrm{HbS}$ positive samples determined through qualitative electrophoresis were detected by solubility test and 20 (86.9\%) were detected by gel-centrifugation test. Conclusion: Hemoglobin electrophoresis proved the best method in the identification of hemoglobin variants and, therefore, worthwhile when it comes to diagnostic screening in blood banks due to its high sensitivity, which keeps false-negative results to a minimum and ensures blood quality. key words

Hemoglobin S

Sickle cell trait

Solubility test

Gel-centrifuge test

Hemoglobin electrophoresis

1. Mestra em Ciências Farmacêuticas/Análises Clínicas Universidade Federal de Santa Maria (UFSM).

2. Mestranda do curso de pós-graduação em Ciências Farmacêuticas da UFSM.

3. Mestranda do curso de pós-graduação em Ciências Farmacêuticas da UFSM.

4. Mestra em Ciências Farmacêuticas; farmacêutica do Hospital Militar de Cruz Alta-RS.

5. Aluna da graduação em Farmácia da UFSM; bolsista pela Fundação de Amparo à Pesquisa do Estado do Rio Crande do Sul (FAPERCS).

6. Doutora em Farmácia; professora adjunta da disciplina de Análises Hematológicas da Faculadade de Farmácia da Universidade Federal do Rio Grande do Sul (UFRCS).

7. Hematologista; médica do Hospital Universitário de Santa Maria (HUSM).

8. Doutor em Farmácia; professor titular da disciplina de Hematologia do curso de Farmácia da UFSM.

Suporte Financeiro: Coordenação de Aperfeiçoamento de Pessoal de Nível Superior (CAPES) e Fundação de Apoio à Pesquisa do Rio Crande do Sul (FAPERCS). 


\section{Introdução}

A anemia falciforme é uma das hemoglobinopatias mais frequentes no mundo, sendo a sua causa uma mutação que afeta os genes beta localizados no braço curto dos dois cromossomos 11, cuja consequência é a substituição, na posição 6, das duas moléculas de globina beta do aminoácido ácido glutâmico por valina. Com isso, origina-se uma hemoglobina anormal, denominada hemoglobina $S$ $(\mathrm{HbS})$, ao invés da hemoglobina normal, denominada hemoglobina $A(\mathrm{HbA})^{(1,2,11,20)}$.

O traço falciforme ou traço siclêmico caracteriza o portador de hemoglobina S, heterozigoto (HbAS), que não apresenta a doença nem possui anormalidades no número e na forma das hemácias ${ }^{(14,19)}$. Os heterozigotos do gene da $\mathrm{HbS}$ portadores do traço falciforme possuem um percentual de hemoglobina anômala que varia de $22 \%$ a $45 \%$ da hemoglobina total ${ }^{(18,19)}$. Estes portadores são geralmente assintomáticos, não apresentam anormalidade física e sua expectativa de vida é semelhante à da população em geral(2). Seus achados hematológicos são aparentemente normais, sem anemia, com níveis de hemoglobina variando de 13 a $15 \mathrm{~g} / \mathrm{dl}$ e volume corpuscular médio (VCM) de 80 a $90 \mathrm{fL}$. Embora o traço falciforme seja assintomático, há relatos de morte súbita e complicações clínicas, especialmente quando os portadores são expostos a condições extremas de baixa tensão de oxigênio, como anestesia geral, mergulho, voo em aviões despressurizados e também na desidratação, em esforços físicos extenuantes, infecções respiratórias graves, insuficiência cardíaca respiratória e episódios de acidose, que podem levar à falcização das hemácias ${ }^{(8,3,10,14,15,18,19)}$.

Uma grande variedade de testes qualitativos e quantitativos permite a detecção da $\mathrm{HbS}$. Entre eles são amplamente conhecidos o teste de solubilidade e a eletroforese de hemoglobinas, mas também alguns testes são comercializados na forma de kit, como o teste em gel-centrifugação, da Diamed ID-HbS. Outras técnicas quantitativas também têm sido utilizadas, como eletroforese por focalização isoelétrica (IEF), cromatografia líquida de baixa pressão (LPLC) e cromatografia líquida de alta performance $(\mathrm{HPLC})^{(4,8,12,16,17,21)}$.

Os portadores do traço falciforme são clínica e hematologicamente saudáveis, portanto aptos à doação de sangue. Assim, para aumentar a eficácia terapêutica das transfusões sanguíneas, a detecção de $\mathrm{HbS}$ em doadores de sangue no Brasil foi indicada pela Portaria oㅜ 1.376, de 19 de novembro de $1993^{(6)}$, mas a triagem das hemoglobinas anormais nos doadores de sangue tornou-se obrigatória a partir de junho de 2004, de acordo com a Resolução de Diretoria
Colegiada da Agência Nacional de Vigilância Sanitária (RDC/ ANVISA) no 153/04(7).

Esta resolução veio ao encontro da necessidade de melhorar cada vez mais a qualidade do sangue a ser transfundido, o que evidencia sua relevância; apesar disso, ela não indica o método de diagnóstico de detecção que deve ser realizado para seu cumprimento. Portanto, devido à falta de uma padronização nos bancos de sangue do Brasil, torna-se muito importante a estandardização de uma técnica para a triagem de hemoglobinas variantes Assim, o presente trabalho teve como objetivo comparar diferentes métodos de triagem para a detecção de $\mathrm{HbSs}$ disponíveis no mercado em doadores do banco de sangue do HUSM.

\section{Metodologia}

\section{Amostra}

No período de abril de 2007 a abril de 2008, foram realizados três métodos de deteç̧ão de $\mathrm{HbS}$ em 4.108 doadores de sangue aptos que se apresentaram ao banco de sangue do HUSM.

As amostras de sangue foram colhidas por punção venosa durante o processo de doação, em tubos com anticoagulante ácido etilenodiaminotetracético (EDTA). Essas amostras foram utilizadas no laboratório de sorologia do banco de sangue do HUSM para detecção de HbS e, depois, levadas para o laboratório de pesquisa do Centro de Ciências da Saúde da Universidade Federal de Santa Maria (UFSM). O projeto foi aprovado pelo CEP/UFSM 23081.015229/2006-95.

\section{Materiais e métodos}

As amostras de sangue dos doadores foram submetidas paralelamente aos seguintes testes de triagem para $\mathrm{HbS}$ : de solubilidade ${ }^{(14)}$, de gel-centrifugação, que utiliza o kit Diamed ID-HbS, e a eletroforese qualitativa em acetato de celulose $\mathrm{pH} 8,5^{(14)}$. Para a confirmação da presença da $\mathrm{HbS}$ nos testes de triagem foi utilizada a eletroforese quantitativa em gel de agarose $\mathrm{pH}$ 9,5 utilizando os reagentes da CELMGEL-Hemoglobina Alcalina.

\section{Resultados}

Foram analisados 4.108 doadores de sangue pelos métodos de solubilidade, gel-centrifugação Diamed ID-HbS 
e eletroforese alcalina qualitativa em fitas de acetato de celulose. Dos doadores estudados, 23 (0,56\%) apresentaram resultado positivo para a presença de $\mathrm{HbS}$ e dois $(0,05 \%)$, resultado positivo para a presença de $\mathrm{HbC}$.

As amostras positivas para $\mathrm{HbS}$ e $\mathrm{HbC}$ foram detectadas por eletroforese de hemoglobina qualitativa em fitas de acetato de celulose $\mathrm{pH} 8,5$ e confirmadas por eletroforese quantitativa em gel de agarose $\mathrm{pH} 9,5$. Das 23 amostras positivas para $\mathrm{HbS}, 22(95,6 \%)$ foram detectadas pelo teste de solubilidade e $20(86,9 \%)$ pelo de gel-centrifugação. Uma das amostras positivas para a $\mathrm{HbS}$ foi detectada somente por eletroforese alcalina.

A frequência para a presença da $\mathrm{HbS}$ nos doadores de sangue pela eletroforese de hemoglobinas foi de 23 $(0,56 \%)$; pelo de solubilidade, $22(0,53 \%)$; e pelo teste de gel-centrifugação, $20(0,49 \%)$. O teste de solubilidade apresentou $95,6 \%$ de sensibilidade e o de gel-centrifugação Diamed ID-HbS, 86,9\% quando em comparação com a eletroforese de hemoglobina, e ambos mostraram-se $100 \%$ específicos (Tabela).

\begin{tabular}{|c|c|c|}
\hline \multicolumn{3}{|c|}{$\begin{array}{l}\text { Desempenho dos testes de triagem } \\
\text { para HbS }\end{array}$} \\
\hline Testes/HbS & $\begin{array}{c}\text { HbS } \\
\text { presente }\end{array}$ & $\begin{array}{c}\mathrm{HbS} \\
\text { ausente }\end{array}$ \\
\hline Eletroforese hemoglobina & $\begin{array}{c}23 \\
(0,56 \%)\end{array}$ & $\begin{array}{c}4.085 \\
(99,44 \%)\end{array}$ \\
\hline Teste de solubilidade & $\begin{array}{c}22 \\
(0,53 \%)\end{array}$ & $\begin{array}{c}4.086 \\
(99,47 \%)\end{array}$ \\
\hline Teste de gel-centrifugação & $\begin{array}{c}20 \\
(0,49 \%)\end{array}$ & $\begin{array}{c}4.088 \\
(99,51 \%)\end{array}$ \\
\hline
\end{tabular}

HbS: hemoglobina S.

\section{Discussão}

Várias metodologias de diferentes graus de sensibilidade têm sido utilizadas para a detecção da HbS. Em nosso estudo, a eletroforese de hemoglobina foi capaz de detectar o maior número de amostras positivas para o gene $\mathrm{S}$. $\mathrm{O}$ teste de solubilidade demonstrou boa especificidade e menor sensibilidade, não sendo capaz de detectar uma amostra positiva. Oshiro et al. ${ }^{(16)}$ compararam o teste de solubilidade, o de falcização e o de gel-centrifugação mostrando não haver discrepância entre eles em 28 amostras de HbAS analisadas de um total de 836 amostras de pacientes de pré-natal estudadas. Prudêncio et al..$^{(17)}$ demonstraram resul- tados $100 \%$ compatíveis entre as técnicas de solubilidade e de gel-centrifugação em 5.416 doadores de sangue, sendo 50 (0,92\%) amostras com HbAS. Nesse mesmo estudo os autores compararam as técnicas de solubilidade, gel-centrifugação e eletroforese de hemoglobina em 213 negros e afro-descendentes e encontraram 18 (8,54\%) portadores de $\mathrm{HbAS}$, sendo que esta amostra também apresentou $100 \%$ de compatibilidade entre as técnicas.

Estudo de Surve et al. ${ }^{(21)}$ detectou, pelo teste de solubilidade, 871 portadores de HbS dos 932 detectados por HPLC e eletroforese; assim, a solubilidade mostrou sensibilidade de $93,8 \%$ e especificidade de $100 \%$. Apesar da menor sensibilidade, vários autores recomendam o teste de solubilidade ou gel-centrifugação como triagem em massa por sua facilidade e seu baixo custo, mas com confirmação dos resultados positivos por outros métodos quantitativos. Sabe-se que o teste de solubilidade não apresenta boa sensibilidade para detecção da presença de $\mathrm{HbS}$ no período neonatal, especialmente nos recém-nascidos (RNs) prematuros, uma vez que neste período ainda não houve a transição de $\mathrm{HbF}$ para hemoglobina do adulto(5). Além disso, Prudêncio et al. ${ }^{(17)}$ citam algumas condições que podem causar resultados falsos positivos, como policitemia, mieloma múltiplo, transfusão recente e insuficiência renal crônica, e falsos negativos, como baixa quantidade de hemoglobina. Mas, como essas condições contraindicam as doações de sangue, elas não ocorreram em nosso estudo e não seriam frequentes nos bancos de sangue.

Quanto ao teste de gel-centrifugação, houve três amostras com resultado falso negativo. Essa discordância no teste de gel-centrifugação deve-se provavelmente a problemas no preparo do agente redutor, que requer alguns cuidados quanto à reconstituição do liofilizado, necessitando de água bidestilada e leve agitação por inversão, além de a estabilidade ser de apenas 2 horas após a reconstituição.

O estudo realizado por Balasubramaniam et al.(4) avaliou o kit da Diamed ID-Sickle Cell Test. Foram analisadas 131 amostras de sangue contendo hemoglobinas normais e variantes (75 amostras contendo $\mathrm{HbS}$ ) determinadas por várias técnicas, como eletroforese alcalina e ácida, HPLC e teste de solubilidade. Os resultados do estudo mostraram baixa sensibilidade do kit para detectar as amostras com $\mathrm{HbS}$, não recomendando o uso, a não ser que a melhora do desempenho seja demonstrada.

A eletroforese de hemoglobina apresentou-se como melhor método para detecção das hemoglobinas variantes, inclusive detectando a $\mathrm{HbC}$, que os outros dois testes não 
encontraram. Analisando os custos envolvidos, o preço por exame para detecção de $\mathrm{HbS}$ pelo método de solubilidade é bem menor em relação ao teste de gel-centrifugação ID $\mathrm{HbS}$ (Diamed) e à eletroforese de hemoglobinas. Além disso, outras vantagens recairiam sobre o teste de solubilidade, como facilidade, praticidade e rapidez na execução, estabilidade e durabilidade dos reagentes, e também não necessitando de grandes investimentos em treinamento de pessoal.
Apesar de a eletroforese de hemoglobinas ser um método que exige maior tempo para a execução e ter um custo um pouco mais elevado, representou a melhor metodologia na identificação de hemoglobinas variantes, portanto deve ser valorizada quando se trata de diagnóstico para triagens em bancos de sangue pelo seu grau de sensibilidade, minimizando ao máximo resultados falsos negativos e garantindo a qualidade e a segurança necessárias aos processos transfusionais.

\section{Referências}

1. ALVES, R. T. et al. Hemoglobinas AS/alfatalassemia: importância diagnóstica. Rev Bras Hemato. Hemoter, v. 22, n. 3, p. 388-94, 2000.

2. ANVISA. Manual de diagnóstico e tratamento de doenças falciformes. 2002. p. 142

3. ARAÚJO, M. C. P. E. et al. Prevalência de hemoglobinas anormais em recém-nascidos da cidade de Natal, Rio Grande do Norte, Brasil. Cad. Saúde Pública, v. 20, n. 1, p. 123-8, 2004.

4. BALASUBRAMANIAM, J. et al. Evaluation of a new screening test for sickle cell haemoglobin. Clin Lab Haem, v. 23, p. 379-83, 2001.

5. BANDEIRA, F. M. G. C. et al. Diagnóstico da hemoglobina S: análise comparativa do teste de solubilidade com a eletroforese em $\mathrm{pH}$ alcalino e ácido no período neonatal. Rev Bras Saúde Materno-Infantil, v. 3, n. 3, p. 265-70, 2003.

6. BRASIL. Ministério da Saúde. Gabinete do Ministro. Portaria no 1.376 , de 19 de novembro de 1993. Aprova as alterações da Portaria no 721/GM, de 9/8/89, que aprova as normas técnicas para coleta, processamento e transfusão de sangue, componentes e derivados, e dá outras providências. Brasília, Diário Oficial da União, p. 18404, 2 de dezembro de 1993.

7. BRASIL. Ministério da Saúde. Gabinete do Ministro. Portaria no 153 , de 14 de junho de 2004. Aprova as normas técnicas para coleta, processamento e transfusão de sangue, componentes e derivados e dá outras providências. Brasília, DF, 2004.

8. Elghetany, M. T.; Davey, F. R. Doenças eritrocitárias. In: HENRY, J. B. Diagnósticos clínicos e tratamento por métodos laboratoriais. São Paulo: Editora Manole, 1999. p. 617-63.

9. EMBURY, S. H. Anemia falciforme e hemoglobinopatias associadas. In: BENNETT, J. C.; PLUM, F. Cecil tratado de medicina interna. Rio de Janeiro: Guanabara Koogan, 1997. cap. 131, p. 976-88.

10. GRIGNANI, C. et al. Prevalência de traço falciforme em doadores de sangue da região de Londrina, Paraná. Rev Bras Anal Clin, v. 38, n. 4, p. 259-62, 2006.

11. LOUREIRO, M. M.; ROZENFELD, S. Epidemiologia de internações por doença falciforme no Brasil. Rev Saúde Pública, v. 39, n. 6, p. 943-9, 2005.
12. LUKENS, J. N. Hemoglobinopatias S, C, D, E \& O e doenças associadas. In: LEE, G. R. et al. Wintrobe hematologia clínica. 9. ed. São Paulo: Manole, 1998. cap. 38, p. 1161-205

13. MURAO, M. et al. Traço falciforme: heterozigose para hemoglobina S. Rev Bras Hematol Hemoter, v. 29, n. 3, p. 223-5, 2007.

14. NAOUM, P. C. Hemoglobinopatias e talassemias. São Paulo: Editora Sarvier; 1997

15. OULD AMAR, A. K. Red blood cells from donors with sickle cell trait: a safety issue for transfusion? Transfus Med, v. 16, p. 248-53, 2006.

16. OSHIRO, M. et al. Estudo comparativo entre os testes de solubilidade, falcização e gel-centrifugação para detecção populacional da hemoglobina S. Rev Inst Adolfo Lutz, v. 58, n. 2, p. 53-6, 1999.

17. PRUDÊNCIO, B. C. A. B. et al. Comparação de metodologia utilizada para a detecção de hemoglobina S ( HbS) em doadores de sangue. Rev Bras Hematol Hemoter, v. 22, n. 2, p. 99-109, 2000.

18. RAMALHO, A. S. Hemoglobina S em doadores de sangue brasileiros. Rev Ass Med Bras, v. 22, p. 467-68, 1976.

19. SILVA, R. B. P.; RAMALHO, A. S. Riscos e benefícios da triagem genética: o traço falciforme como modelo de estudo em uma população brasileira. Cad Saúde Pública, Rio de Janeiro, v. 13, n. 2, p. 285-94, 1997.

20. SILVA, M. C.; SHIMAUTI, E. L. T. Eficácia da hidroxiuréia em crianças com anemia falciforme. Rev Bras Hematol Hemoter, v. 28, n. 2, p. 144-8, 2006.

21. SURVE, R. R. et al. Deteccion of the S gene: an evaluation of the solubility test against automated chromatography and haemoglobin electrophoresis. Br J Biomed Sci, v. 57, p. $292-4,2000$

Endereço para correspondência

José Edson Paz da Silva Coordenação do Curso de Farmácia Centro de Ciências da Saúde Universidade Federal de Santa Maria Campus Universitário Camobi CEP 97105-900 - Santa Maria-RS 